\title{
Primary mechanism of apoptosis induction in a leukemia cell line by fraction FA-2-b- $\beta$ prepared from the mushroom Agaricus blazei Murill
}

\section{Gao ${ }^{1}$, Y. Sun ${ }^{2}$, \\ C. Chen ${ }^{3}, Y . \mathrm{Xi}^{4}$, \\ J. Wang ${ }^{5}$ and Z. Wang ${ }^{1}$}

\author{
${ }^{1}$ School of Life Sciences, Lanzhou University, \\ 2People's Hospital of Gansu Province, \\ ${ }^{3}$ Scientific Research Center, Gansu College of TCM, \\ ${ }^{4}$ First Hospital of Lanzhou University, \\ ${ }^{5}$ Institute of Hematology, Lanzhou University, Lanzhou, P.R. China
}

\begin{abstract}
Correspondence

Z. Wang

School of Life Sciences

Lanzhou University

Lanzhou 730000

Gansu Province

P.R. China

Fax: +86-0931-826-6957

E-mail: shjun@public.lz.gs.cn,

wangzr@lzu.edu.cn

Received October 13, 2006

Accepted August 6, 2007

Agaricus blazei Murill is a native Brazilian mushroom which functions primarily as an anticancer substance in transplanted mouse tumors. However, the mechanism underlying this function of A. blazei Murill remains obscure. The present study was carried out to investigate the effect of fraction FA-2-b- $\beta$, an RNA-protein complex isolated from A. blazei Murill, on human leukemia HL-60 cells in vitro. Typical apoptotic characteristics were determined by morphological methods using DNA agarose gel electrophoresis and flow cytometry. The growth suppressive effect of fraction FA-2-b- $\beta$ on HL-60 cells in vitro occurred in a dose- $(5-80 \mu \mathrm{g} / \mathrm{mL})$ and time-dependent $(24-96 \mathrm{~h})$ manner. The proliferation of HL-60 cells $\left(1 \times 10^{5}\right.$ cells $\left./ \mathrm{mL}\right)$ treated with $40 \mu \mathrm{g} / \mathrm{mL}$ of fraction FA-2-b-ß for $24-96 \mathrm{~h}$ and with $5-80 \mu \mathrm{g} / \mathrm{mL}$ for $96 \mathrm{~h}$ resulted in inhibitory rates ranging from 8 to $54.5 \%$, and from 4.9 to $86.3 \%$, respectively. Both telomerase activity determined by TRAP-ELISA and mRNA expression of the caspase- 3 gene detected by RT-PCR were increased in HL-60 cells during fraction FA-2-b- $\beta$ treatment. The rate of apoptosis correlated negatively with the decrease of telomerase activity $(\mathrm{r}=0.926, \mathrm{P}<0.05)$, but correlated positively with caspase- 3 mRNA expression $(\mathrm{r}=0.926, \mathrm{P}<0.05)$. These data show that fraction FA-2-b- $\beta$ can induce HL-60 cell apoptosis and that the combined effect of down-regulation of telomerase activity and up-regulation of mRNA expression of the caspase- 3 gene could be the primary mechanism of induction of apoptosis. These findings provide strong evidence that fraction FA-2-b- $\beta$ could be of interest for the clinical treatment of acute leukemia.
\end{abstract}

Key words

- Agaricus blazei Murill

- Fraction FA-2-b-ß

- Apoptosis

- Caspase-3

- Telomerase

- HL-60 cells

\section{Introduction}

Agaricus blazei Murill is an edible native Brazilian mushroom which has been widely used in traditional medicine. The mushroom is also widely produced in Japan and China, where it is consumed as food and tea for its medical effects. Some polysaccharides and protein-bound polysaccharides isolated from A. blazei Murill have been shown to have 
anticancer activity directly or through immunomodulation (1-4). More biological activities of A. blazei Murill, such as antimutation (5), sterilization (6) and anti-angiogenic (7) activities, to list a few, have been reported (8). Additionally, constituents such as RNA-protein complex have been found in the fruiting body. In the past several decades, polysaccharides have emerged as an important class of bioactive natural products having pharmacological functions such as anticancer, anti-inflammatory, and immunopotentiating effects (9). In recent years, many effective anticancer drugs have been developed, and natural plant ingredients with anticancer effects have attracted much attention (10). Song et al. (11) reported that curcumin induces human HT-29 colon adenocarcinoma cell apoptosis.

We are also interested in the discovery of natural products but with minimal systemic side effects compared with known ones. Research has indicated that the primary medical effect of A. blazei Murill is its anticancer activity in tumor-bearing mice (12). A. blazei Murill has been reported to be very effective against some malignancies, and possible explanations of its anticancer action have been proposed $(2,3,7,8)$. The details of the mechanism, however, are still unclear. Clinical studies conducted by our group have shown that when patients with leukocythemia were treated with a crude extract (not fraction FA-2-b- $\beta$ ) of $A$. blazei Murill, their humoral immune function would be particularly stimulated, and that treatment with the extract had an inhibitory effect on leukemia cells in acute nonlymphocytic leukemia patients (13).

Fraction FA-2-b- $\beta$, a novel RNA-protein complex, was isolated from A. blazei Murill. It consists of three constructs: an RNA molecule whose molecular weight was 10,000, $15.7 \%$ protein, and D-ribose as the major constitutive sugar. The $[\alpha]_{D}$ value of the complex was $+58.6^{\circ}\left(\mathrm{H}_{2} \mathrm{O}\right)$ and a UV-spectrum showed a pattern specific for nucleic acids. Adenine, aminopurine, chloropurine, glycoprotein, and some other modified bases were detected as nucleic acid base components (12). On this basis, in the present study, we investigated the anticancer effects of fraction FA-2-b- $ß$ on HL-60 cells in vitro for an explanation of the anticancer function of $A$. blazei Murill and the primary mechanisms of this activity.

\section{Material and Methods}

3-[4,5-Dimethylthiazol-2-y]-2,5-diphenyltetrazolium bromide (MTT), sodium dodecyl sulfate (SDS), RPMI-1640, phosphate-buffered solution (PBS), propidium iodide, acridine orange, and proteinase $\mathrm{K}$ were purchased from Sigma, St. Louis, MO, USA. The RNA extract kit, RT-PCR kit and telomerase PCR ELISA kit were supplied by Sino-American Biotechnology Company, Luoyang, P.R. China. Caspase-3 primers were purchased from Shanghai Biological Technique Service Company, Ltd., Shanghai, P.R. China.

\section{Plant material}

A. blazei Murill was kindly provided by the School of Medicine, Mie University, Tsu, Mie, Japan. The active RNA-protein complex, fraction FA-2-b- $\beta$, was extracted and identified by the School of Chemistry and Chemical Engineering, Lanzhou University, P.R. China. The methods for its extraction have been previously reported (12). Briefly, dried plant material (500 g) was powdered and the powder was fractionated with hot water. The extract obtained was purified and its compounds were detected by ethanol precipitation, gel filtration, DEAE-cellulose, and Sephadex G-200 column chromatography. Finally, a total of 4.86 $\mathrm{g}$ fraction FA-2-b- $\beta$ was obtained, dissolved in twice-distilled water, and stored at $4^{\circ} \mathrm{C}$.

\section{Cell culture}

The human leukemia cell line HL-60 was 
obtained from the Institute of Hematology of Lanzhou University, P.R. China, and maintained at $37^{\circ} \mathrm{C}$ in a humidified atmosphere of $95 \%$ air and $5 \% \mathrm{CO}_{2}$ in RPMI-1640 supplemented with $10 \%(\mathrm{v} / \mathrm{v})$ heat-inactivated fetal bovine serum, penicillin ( $100 \mathrm{kU} / \mathrm{L})$, streptomycin $(100 \mathrm{mg} / \mathrm{L})$, and $2 \mathrm{mM}$ glutamine. Exponentially growing cells were used throughout the study.

\section{Cell viability}

Cell viability was determined by the MTT assay (14). Briefly, aliquots of HL-60 cells containing $1 \times 10^{5}$ cells $/ \mathrm{mL}$ were added to each well of a 96-well flat-microtiter plate and incubated with various doses of fraction FA-2-b- $B(0,5,10,20,40$, and $80 \mu \mathrm{g} / \mathrm{mL})$. Six replicate wells were used for each point in the experiment. After 24, 48, 72, and $96 \mathrm{~h}$, $10 \mu \mathrm{L}$ MTT solution $(5 \mathrm{mg} / \mathrm{mL}$ in PBS) stored at $4^{\circ} \mathrm{C}$ in a dark bottle was added to each well and then the plates were incubated for $4 \mathrm{~h}$ at $37^{\circ} \mathrm{C}$. Extraction buffer (10\% SDS$10 \mathrm{mM} \mathrm{HCl}$ ) was added. After an overnight incubation at $37^{\circ} \mathrm{C}$, absorbance at $570 \mathrm{~nm}$ was measured using a BioRad 550 ELISA microplate reader (BioRad Laboratories, Hercules, CA, USA). The inhibition rates were calculated as follows: inhibition rates $(\%)=[($ mean absorbance of control $)$ - (mean absorbance of the experiment)] / (mean absorbance of control) x $100 \%$.

\section{Apoptosis evaluation}

Apoptosis was evaluated by two criteria: 1) DNA fragmentation, monitored by the appearance of a DNA ladder on agarose gel electrophoresis, and 2) morphological changes in the nuclear structure, stained with acridine orange. The apoptotic cells were counted under a fluorescent microscope in each experiment, and at least three optical fields were counted in each of them, containing a total of 200 cells. The percentage of apoptotic cells was calculated as follows: percentage of apoptotic cells $=$ number of apoptotic cells / total cells counted (200 usually) x $100 \%$.

\section{Electron microscopy}

HL-60 cells treated with fraction FA-2b- $3(40 \mu \mathrm{g} / \mathrm{L})$ for $96 \mathrm{~h}$ were fixed with $1 \%$ glutaraldehyde in PBS, $\mathrm{pH} 7.2$, for $1 \mathrm{~h}$ at $37^{\circ} \mathrm{C}$. The cells were then washed with PBS, postfixed with $1 \% \mathrm{OsO}_{4}$, dehydrated in a graded ethanol series, infiltrated with propylene oxide, and embedded in Epon. Ultrathin sections were obtained, counterstained with $4 \%$ uranium acetate and lead nitrate, and examined with a transmission electron microscope (H-600, Hitachi Ltd., Hadano, Kanagawa, Japan).

\section{DNA agarose gel electrophoresis}

After treatment with fraction FA-2-b- 3 $(5,10,20,40$, and $80 \mu \mathrm{g} / \mathrm{mL})$, HL-60 cells were lysed in a solution containing $500 \mathrm{mM}$ Tris-HCl, pH 8.0, $20 \mathrm{mM} / \mathrm{L}$ EDTA, $10 \mathrm{mM} /$ $\mathrm{L} \mathrm{NaCl}, 1 \%(\mathrm{w} / \mathrm{v}) \mathrm{SDS}$, and $100 \mu \mathrm{g} / \mathrm{mL}$ proteinase $\mathrm{K}$, at $37^{\circ} \mathrm{C}$ for $48 \mathrm{~h}$. The DNA was extracted by the standard phenol-chloroformisoamyl alcohol extraction procedure as described previously (15) and treated with 100 $\mu \mathrm{g} / \mathrm{mL}$ RNase A at $37^{\circ} \mathrm{C}$ for $30 \mathrm{~min}$. DNA samples were electrophoretically separated on $1.2 \%$ agarose gels at $60 \mathrm{~V}$ for $1-2 \mathrm{~h}$, the gels were stained with ethidium bromide, and the DNA was visualized under UV light and photographed.

\section{Cell flow cytometry}

The percentages of apoptotic cells and their stage in the cell cycle were detected by cell flow cytometry. Briefly, after treatment with fraction FA-2-b- $\beta(0,5,10,20,40$, and $80 \mu \mathrm{g} / \mathrm{mL})$ for regular intervals $(24,48,72$, and $96 \mathrm{~h}$ ), HL-60 cells were prepared as a single cell suspension in $200 \mu \mathrm{L}$ PBS, pH 7.2 , fixed with $2 \mathrm{~mL}$ ice-cold $70 \%$ ethanol, 
and maintained at $4^{\circ} \mathrm{C}$ overnight. The cells were harvested by centrifugation at $500 \mathrm{~g}$ for $10 \mathrm{~min}$, resuspended in $500 \mu \mathrm{L}$ PBS, pH 7.2, supplemented with $0.1 \%$ Triton X-100 and RNase $(100 \mu \mathrm{g} / \mathrm{mL})$, and incubated in a dark room. After $30 \mathrm{~min}$ at $37^{\circ} \mathrm{C}$, the cells were analyzed on a flow cytometer (B.D., FACSCalibur, Franklin Lakes, NJ, USA).

\section{Telomerase assay}

The telomerase PCR ELISA kit used was an extension of the original method (16). After HL-60 cells $\left(1 \times 10^{5}\right.$ cells $\left./ \mathrm{mL}\right)$ were treated with fraction FA-2-b- $\beta(0,5,10,20$, 40 , and $80 \mu \mathrm{g} / \mathrm{mL}$ ) for $96 \mathrm{~h}$, the cells were harvested, washed and centrifuged at $500 \mathrm{~g}$ for $10 \mathrm{~min}$ at $4^{\circ} \mathrm{C}$. The pellet was washed by adding $150 \mu \mathrm{L}$ washing solution and centrifuged at $500 \mathrm{~g}$ for $10 \mathrm{~min}$, and then solubilized with $50 \mu \mathrm{L}$ lysis buffer, suspended, icebathed for $30 \mathrm{~min}$, and centrifuged at 12,000 $g$ for $20 \mathrm{~min}$ at $4^{\circ} \mathrm{C}$. A $2-\mu \mathrm{L}$ aliquot of the supernatant was used as template for the telomeric repeat amplification protocol. A $45-\mu \mathrm{L}$ amount of the reaction solution was added to the test tube containing $2 \mu \mathrm{L}$ of the prepared sample, and, after thorough mixing, $30 \mu \mathrm{L}$ liquid paraffin was added to the tube and the mixture was incubated in a water bath at $25^{\circ} \mathrm{C}$ for $30 \mathrm{~min}$. The PCR conditions were as follows: 35 cycles of 120 s each: $30 \mathrm{~s}$ at $94^{\circ} \mathrm{C}, 30 \mathrm{~s}$ at $90^{\circ} \mathrm{C}, 90 \mathrm{~s}$ at $48^{\circ} \mathrm{C}$, and $300 \mathrm{~s}$ at $72^{\circ} \mathrm{C}$. The amplification product $(5 \mu \mathrm{L})$ was mixed with $20 \mu \mathrm{L}$ denaturation reagent and incubated at room temperature for $10 \mathrm{~min}$.

A $225-\mu \mathrm{L}$ aliquot of hybridization buffer was added and mixed thoroughly, and 100 $\mu \mathrm{L}$ of the mixture per well was transferred to precoated microtiter plate wells and incubated at $37^{\circ} \mathrm{C}$ in a shaker for $2 \mathrm{~h}$. Antidigoxin-peroxidase working solution (100 $\mu \mathrm{L}$ ) was added and incubated at room temperature for $30 \mathrm{~min}$ with shaking. The solution was completely removed and the precipitate was rinsed five times with $250 \mu \mathrm{L}$ washing buffer per well for a minimum of 30 s. After removing the washing buffer, 100 $\mu \mathrm{L}$ tetramethyl benzidine substrate solution was added and incubated for color development at room temperature for $20 \mathrm{~min}$ with gentle shaking. Finally, $100 \mu \mathrm{L}$ stop reagent was added to each well to stop color development. The amount of telomeric repeat amplification protocol products was determined by measurement of absorbance at 450 $\mathrm{nm}$ (with a reference wavelength of approximately $690 \mathrm{~nm}$ ) within 30 min after the end of the reaction. Absorbance values were reported as the A450-A690 $\mathrm{nm}$ range.

\section{Assay of caspase-3 mRNA expression}

The expression of caspase- 3 mRNA was determined by RT-PCR. Caspase-3 primer sequences were 5'-GACTACCTCATGAA GATC-3' and 5'-GATCCACATCTGCTGG AA-3' for B-actin, and 5'-GGTATTGA GACAGACAGTGG-3' and 5'-GATGGGAT CTGTTTCTTTGC-3' for caspase-3, as indicated by Yakovlev et al. (17). The molecular weights of the PCR-amplified products were 496 and 288 bp, respectively. Total RNA was extracted from the specimen using an RNA extraction kit according to manufacturer instructions. Caspase-3 mRNA from total RNA was amplified by RT-PCR and semiquantitative analysis of the amplified fragments was carried out using an image analyzer (Alphalmager TM 2200, Alpha Innotech Corporation, San Leandro, CA, USA). RT-PCR conditions were as follows: reverse transcription at $37^{\circ} \mathrm{C}$ for $60 \mathrm{~min}$, predenaturation at $94^{\circ} \mathrm{C}$ for $4 \mathrm{~min}$ followed by 30 cycles at $94^{\circ} \mathrm{C}$ for $30 \mathrm{~s}$, at $55^{\circ} \mathrm{C}$ for 15 $\mathrm{s}$, and at $72^{\circ} \mathrm{C}$ for $45 \mathrm{~s}$, and primer extension at $72^{\circ} \mathrm{C}$ for $7 \mathrm{~min}$. PCR products were submitted to gel electrophoresis at $5 \mathrm{~V} / \mathrm{cm}$ and stained with $0.5 \mathrm{mg} / \mathrm{L}$ ethidium bromide. Results were observed and photographed with an ultraviolet reflectance analyzer (ZF-3, Shanghai Changxing Machinery, Shanghai, China). The 288-bp amplified caspase-3 prod- 
uct was quantified by densitometry and expressed relative to the control gene, $B$-actin.

\section{Statistical analysis}

Data are reported as means \pm SD. For most experiments, the statistical difference was evaluated by the Student $t$-test.

\section{Results}

\section{Fraction FA-2-b-ß-inhibited cell growth}

The cells were treated with various quantities of fraction FA-2-b- $\beta(0-80 \mu \mathrm{g} / \mathrm{mL})$ and viability was determined with the MTT assay. The results are shown in Tables 1 and 2 . Fraction FA-2-b- $\beta$ inhibited the proliferation of HL- 60 cells both in a dose- and timedependent manner. After treatment of HL60 cells with $40 \mu \mathrm{g} / \mathrm{mL}$ fraction FA-2-b- $B$ for 24, 48, 72 and $96 \mathrm{~h}$, we found that the $\mathrm{IC}_{50}$ values of fraction FA-2-b- $\beta$ were 211, 187.35, 89.61 , and $42.72 \mu \mathrm{g} / \mathrm{mL}$, respectively. As can be seen in Table 2, the apoptosis rate increased with concentration within a certain range also in a clearly dose-dependent manner.

\section{Fraction FA-2-b-ß-induced cell apoptosis}

After treatment with $40 \mu \mathrm{g} / \mathrm{mL}$ fraction FA-2-b- 3 for 96 h, HL-60 cells presented cell membrane blebbing, nuclear fragmentation, nucleolysis, and formation of an apoptotic body under the fluorescent microscope (data not shown) and transmission electron microscope (Figure 1). All were typical changes due to cell apoptosis. Exposure of HL-60 cells to different doses of fraction FA-2-b- $\beta$ for different periods of time resulted in increased apoptosis rates, with a high apoptotic rate of $27.0 \%$ when the cells were treated with $40 \mu \mathrm{g} / \mathrm{mL}$ fraction FA-2b- $\beta$ for $96 \mathrm{~h}$ (Figure 2). In addition, the concentration of $40 \mu \mathrm{g} / \mathrm{mL}$ fraction FA-2-b$\beta$ was the best for the induction of apoptosis in HL-60 cells. When the cells were treated
Table 1. Time-dependent effect of $40 \mu \mathrm{g} / \mathrm{mL}$ of the fraction FA-2-b-B extract on the proliferation of HL-60 cells.

\begin{tabular}{lccc}
\hline Time (h) & $\begin{array}{c}\text { Control group } \\
\text { (Absorbance at } 570 \mathrm{~nm})\end{array}$ & $\begin{array}{c}\text { Experimental group } \\
\text { (Absorbance at } 570 \mathrm{~nm})\end{array}$ & Inhibition rate (\%) \\
\hline 24 & $0.24 \pm 0.08$ & $0.22 \pm 0.028^{*}$ & $8.0 \%$ \\
48 & $0.25 \pm 0.17$ & $0.22 \pm 0.013^{* *}$ & $12.0 \%$ \\
72 & $0.27 \pm 0.10$ & $0.18 \pm 0.030^{* *}$ & $33.3 \%$ \\
96 & $0.22 \pm 0.08$ & $0.03 \pm 0.017^{* *}$ & $54.5 \%$ \\
\hline
\end{tabular}

Data are reported as means $\pm S D$ or as percent of the absorbance $(N=6)$ at $570 \mathrm{~nm}$. ${ }^{\star} \mathrm{P}<0.05,{ }^{* *} \mathrm{P}<0.01$ compared to control (Student $\mathrm{t}$-test).

Table 2. Dose-dependent effect of fraction FA-2-b- $\beta$ on the proliferation of HL-60 cells for $96 \mathrm{~h}$.

\begin{tabular}{lcc}
\hline Fraction FA-2-b-B $(\mu \mathrm{g} / \mathrm{mL})$ & Absorbance at $570 \mathrm{~nm}$ & Inhibition rate (\%) \\
\hline 0 (control) & $0.22 \pm 0.080$ & $0.0 \%$ \\
5 & $0.21 \pm 0.070^{*}$ & $4.9 \%$ \\
10 & $0.19 \pm 0.130^{* *}$ & $14.0 \%$ \\
20 & $0.14 \pm 0.050^{* *}$ & $36.4 \%$ \\
40 & $0.10 \pm 0.030^{* *}$ & $54.5 \%$ \\
80 & $0.03 \pm 0.017^{* *}$ & $86.3 \%$ \\
\hline
\end{tabular}

Data are reported as means $\pm S D$ or as percent of the absorbance $(N=6)$ at $570 \mathrm{~nm}$. ${ }^{*} \mathrm{P}<0.05,{ }^{* *} \mathrm{P}<0.01$ compared to control (Student $t$-test).
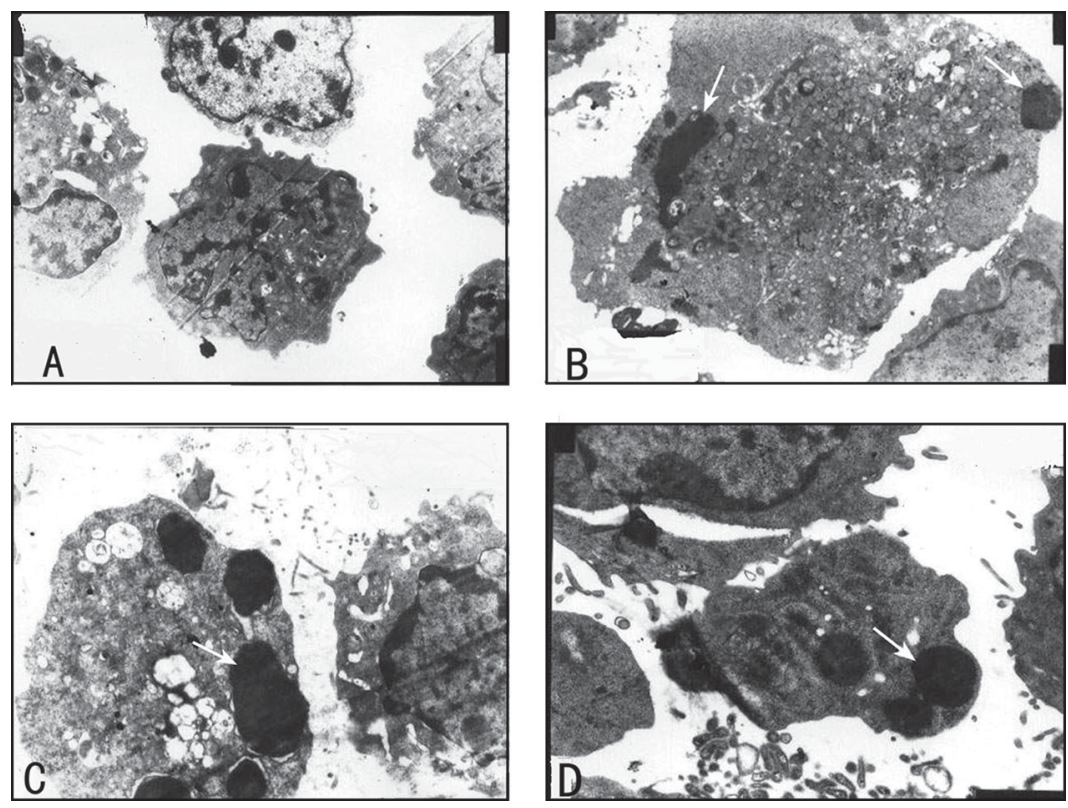

Figure 1. Transmission electron microscopy of untreated HL-60 cells $(A)$ and cells treated with $40 \mu \mathrm{g} / \mathrm{mL}$ fraction FA-2-b-B for $96 \mathrm{~h}$ (B-D). The typical nuclear features of apoptosis, such as marginal condensation of nuclear chromatin (arrows) and nuclear fragmentation (arrows) are shown in figures B-D. Magnification 4000X in A-D. 
with this dose for 24 and $48 \mathrm{~h}$ or for 72,96 , and $120 \mathrm{~h}$, the apoptotic rate was increased, with a significant difference compared to control $(\mathrm{P}<0.05$ or $\mathrm{P}<0.01)$, although the rate was decreased when the cells were treated for $120 \mathrm{~h}$.

\section{DNA agarose gel electrophoresis}

The induction of apoptosis by fraction FA-2-b- $\beta$ was analyzed by measuring DNA fragmentation. As one of the important hall-

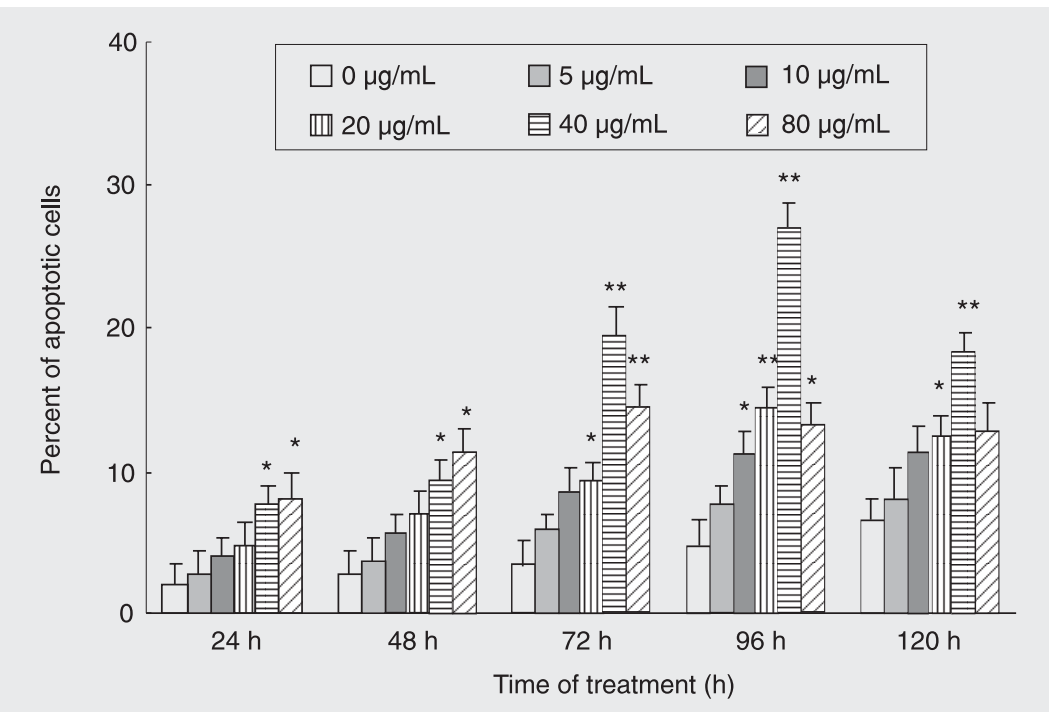

Figure 2. Percentage of apoptotic cells after exposure to different amounts of fraction FA-2$\mathrm{b}-\mathrm{B}$ for different periods of time. The percentage of apoptotic cells was determined by acridine orange staining as described in Material and Methods, with 200 cells being counted for each time. Data are reported as means \pm SD and the apoptotic rate of the experimental groups is compared to control. ${ }^{\star} \mathrm{P}<0.05,{ }^{* \star} \mathrm{P}<0.01 \mathrm{vs}$ the $0 \mu \mathrm{g} / \mathrm{mL}$ group (Student $t$-test).

Figure 3. Effect of fraction FA-2b- $\beta$ on the apoptosis of $\mathrm{HL}-60$ cells showing the DNA ladder on agarose gel. HL-60 cells $\left(1 \times 10^{5}\right.$ cells $/ \mathrm{mL}$ ) were exposed to fraction FA-2-b-B at the indicated doses for 96 h. Lane 1, Control cells; lanes 2-6, cells treated with $5,10,20,40$, and $80 \mu \mathrm{g} / \mathrm{mL}$ fraction FA-2-b- $B$ for $96 \mathrm{~h}$, respectively. $\mathrm{M}=$ molecular size markers (100 bp).

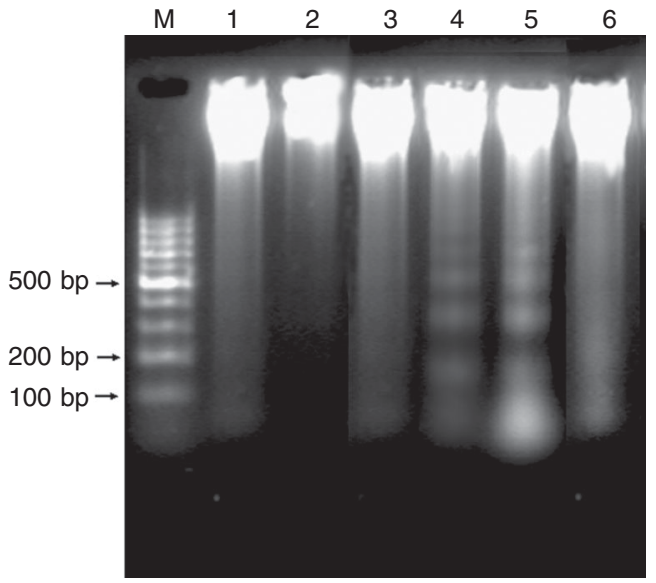

marks of apoptosis, DNA fragmentation into multiples of 180-200 bp appears to be a typical DNA ladder pattern in DNA electrophoresis. In the present study, a conspicuous DNA ladder was observed in the cells treated with fraction FA-2-b- $\beta$, and furthermore the ladder grew with increasing doses of fraction FA-2-b-B up to $80 \mu \mathrm{g} / \mathrm{mL}$ (Figure 3).

\section{DNA content assay}

The loss of DNA is a typical feature of apoptotic cells which is due to diffusion of degraded DNA out of fixed cells after cleavage. As can be clearly seen in Figure 4, apoptosis and sub-G1 peaks occurred in a dose-dependent manner, but the cell cycle did not change. The highest peak of apoptosis was $23.2 \%$ when the cells were treated with $40 \mu \mathrm{g} / \mathrm{mL}$ fraction FA-2-b- $B$ for $96 \mathrm{~h}$. However, the apoptotic rate was reduced when the cells were treated with $80 \mu \mathrm{g} / \mathrm{mL}$ fraction FA-2-b- 3 for $96 \mathrm{~h}$, a fact that might be explained by the effect of cell death by apoptosis.

\section{Reduction of telomerase activation by fraction FA-2-b-ß}

Treatment of HL-60 cells with fraction FA-2-b- $\beta$ reduced their telomerase activity in a dose-dependent manner, especially after administration for $96 \mathrm{~h}$ (Table 3). The data essentially revealed a negative correlation between apoptosis rate and telomerase activity $(r=0.926, P<0.05)$.

Fraction FA-2-b-ß increased caspase-3 mRNA expression

After 96-h treatment of HL-60 cells with different amounts of fraction FA-2-b- $\beta$, caspase-3 mRNA expression increased compared to control. However, after treatment with $80 \mu \mathrm{g} / \mathrm{mL}$ fraction FA-2-b- 3 for $96 \mathrm{~h}$, the mRNA content of the caspase- 3 gene was reduced, an event possibly related to the 

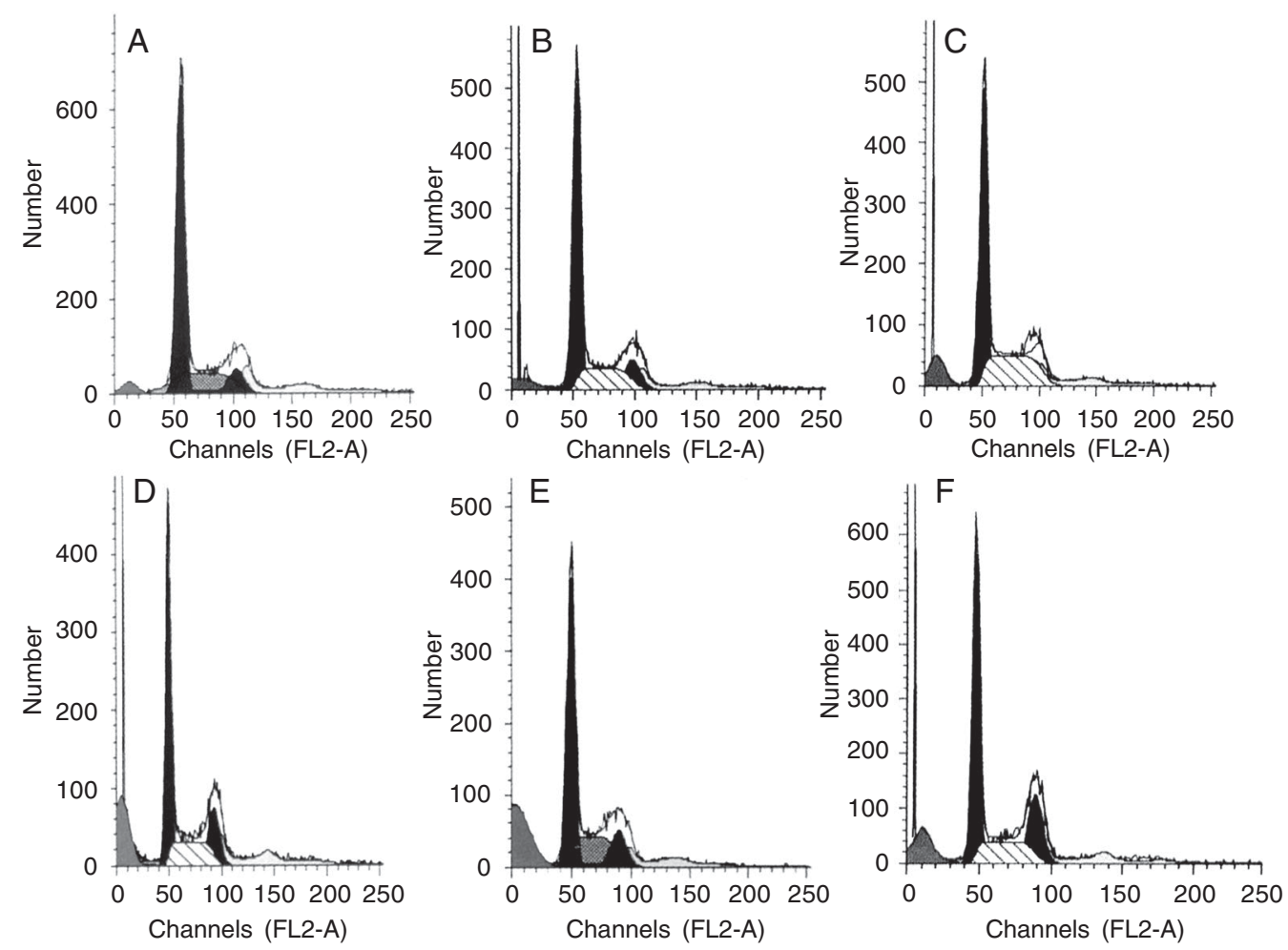

effects of cell apoptosis (Figure 5). Overall caspase-3 mRNA expression was found to be positively correlated with the rate of apoptosis $(\mathrm{r}=0.926, \mathrm{P}<0.05)$.

\section{Discussion}

The majority of current anticancer therapies aim at killing cancer cells by induction of apoptosis (18). In recent years, many studies have reported that different extracts of A. blazei Murill have various anticancer effects, ranging from the improvement of immune-modulatory activity (19-21) to the inhibition of tumor growth via direct inhibition of tumor-induced angiogenesis in mice (7). The results of the present study confirmed that fraction FA-2-b- $\beta$ did induce the apoptosis of HL-60 cells in vitro as indicated by morphological changes, DNA fragmentation and flow cytometry. Additionally, we attempted to demonstrate in vitro that fraction FA-2-b- $\beta$ has an anti-tumor function, most probably owing to its ability to promote cell apoptosis, this possibly being the

\begin{tabular}{|c|c|}
\hline Fraction FA-2-b-ß $(\mu \mathrm{g} / \mathrm{mL})$ & $\begin{array}{l}\text { Absorbance } \\
\text { at } 450-690 \mathrm{~nm}\end{array}$ \\
\hline 0 & $1.39 \pm 0.06$ \\
\hline 5 & $1.33 \pm 0.05$ \\
\hline 10 & $1.24 \pm 0.06^{*}$ \\
\hline 20 & $0.88 \pm 0.02^{\star *}$ \\
\hline 40 & $0.38 \pm 0.03^{\star *}$ \\
\hline 80 & $0.22 \pm 0.02^{* *}$ \\
\hline
\end{tabular}

Data are reported as means $\pm \mathrm{SD}(\mathrm{N}=6)$. ${ }^{*} \mathrm{P}<0.05$, ${ }^{*} \mathrm{P}<0.01$ compared to control (Student $t$-test).

mechanism we were looking for. Further analysis demonstrated that the rate of cell apoptosis changed with different times of treatment and with different doses of fraction FA-2-b- 3 . Within a certain dose range, fraction FA-2-b- $\beta$ showed a significant doseand time-dependent effect on the cell apoptotic rate. The highest apoptotic rates were $23.2 \%$ (determined by flow cytometry after
Figure 4. Flow cytometric analysis of DNA content of HL-60 cells treated with various doses of fraction FA-2-b- 3 for $96 \mathrm{~h}$. A, Medium alone, G1: $66.3 \%$, G2/ M: $10.39 \%$, S: $23.4 \%$, apoptosis: $4.5 \%$. B, $5 \mu \mathrm{g} / \mathrm{mL}$ fraction FA-2-b-B, G1: $62.38 \%$, G2/M: $11.79 \%$, S: $25.83 \%$, apoptosis: 6.18\%. C, $10 \mu \mathrm{g} / \mathrm{mL}$ fraction FA2-b-B, G1: $54.15 \%$, G2/M: $22.76 \%$, S: $23.09 \%$, apoptosis: $9.86 \% . D, 20 \mu \mathrm{g} / \mathrm{mL}$ fraction $\mathrm{FA}$ 2-b-B, G1: $56.89 \%$, G2/M: $18.77 \%$, S: $24.34 \%$, apoptosis: $15.1 \%$. E, $40 \mu \mathrm{g} / \mathrm{mL}$ fraction $\mathrm{FA}$ 2-b-B, G1: $57.11 \%$, G2/M: $14.37 \%$, S: $28.52 \%$, apoptosis: $23.2 \%$. $F, 80 \mu \mathrm{g} / \mathrm{mL}$ fraction $\mathrm{FA}$ 2-b-B, G1: $53.89 \%$, G2/M: $16.76 \%$, S: $29.35 \%$, apoptosis: $18.18 \%$. 
Figure 5. RT-PCR assays of caspase-3 mRNA of HL-60 cells $\left(1 \times 10^{5}\right.$ cells $\left./ \mathrm{mL}\right)$ treated with fraction FA-2-b-B. A, Lanes 1-6: $\mathrm{HL}-60$ cells were treated with 0 , $5,10,20,40$, and $80 \mu \mathrm{g} / \mathrm{mL}$ fraction FA-2-b-B for $96 \mathrm{~h}$, respectively. $B$, The ratio of mRNA content between caspase- 3 and $B$ actin. treatment with $40 \mu \mathrm{g} / \mathrm{mL}$ fraction FA-2-b- $\beta$ for $96 \mathrm{~h}$ ) and $27 \%$ (determined by counting apoptotic cells stained with acridine orange after the same dose and time of treatment). The apoptotic rates detected by these two methods were similar, indicating that the methods used here are feasible.

However, a reduction of apoptotic rate at $40 \mu \mathrm{g} / \mathrm{mL}$ of fraction FA-2-b- $\beta$ treated for $120 \mathrm{~h}$ was detected by counting apoptotic cells. This reduction was $18.41 \%$, which was $<27.0 \%$ detected at the same concentration for $96 \mathrm{~h}$ detected by the same method (Figure 2). At $80 \mu \mathrm{g} / \mathrm{mL}$ of fraction FA-2-b$B$ treated for $96 \mathrm{~h}$, detected by flow cytometry, the reduction was $18.18 \%$, which was $<23.2 \%$ detected at $40 \mu \mathrm{g} / \mathrm{mL}$ for the same treatment duration by the same method (Figure 4). These might be attributed to two reasons: one was normal cell death with prolongation of treatment time as observed in the control group, and the other was cell apoptotic death that was caused by higher concentrations and longer duration of treatment with fraction FA-2-b-ß. The results of the present study demonstrate that fraction FA-2-b-8 can inhibit HL-60 cell proliferation and induce HL-60 cell apoptosis in vitro, as shown by different methods, with a significant time- and dose-dependent effect (Tables 1 and 2).

Whenever a natural plant extract is used for medicinal purposes, its toxicity should

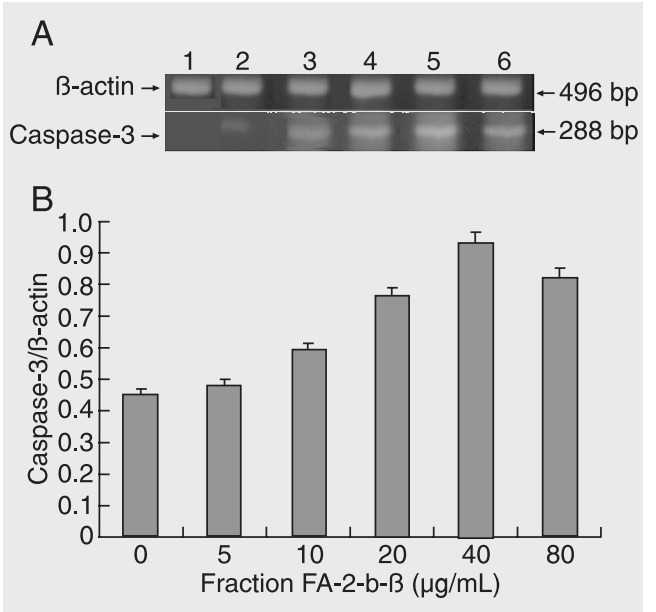

be a preliminary consideration. As part of the assessment of the safety of the A. blazei Murill extract, a 90-day study of subchronic toxicity was performed in F344 rats. The results showed no remarkable toxic effects even when the diet contained as much as 5\% of this plant (22). In addition, previous studies have shown that A. blazei polysaccharide can promote the proliferation, maturation and release of hematopoietic stem cells and progenitor cells in normal and radiationinjured mice, respectively $(23,24)$. Our previous clinical observations indicated that patients with leukocythemia or with gastrointestinal malignancies treated with a crude extract of A. blazei Murill displayed promotion of normal hemopoiesis and humoral immune function and an inhibitory effect on leukemia cells $(12,25)$. Recent studies have shown that a lectin isolated from the mushroom Boletopsis leucomelas induced apoptosis in U937 cells in vitro (26) and B-glucan extracted from A. blazei Murill had a suppressive effect on spontaneous and disseminated peritoneal metastases in a mouse model (27). The results of the present study agree with those reported in the cited studies, suggesting that fraction FA-2-b- $\beta$ and other A. blazei Murill extracts have preventive effects against cancer by inducing apoptosis in vitro and in vivo, with hardly detected adverse effects on normal cells.

The telomerase enzymes characterized to date are RNA-dependent DNA polymerases that synthesize the telomeric DNA repeats by using an RNA template existing as a subunit of the telomerase holoenzyme. Telomerase is active in stabilizing the telomeres of certain self-renewing cell populations and most malignant cells, but is not expressed in most normal human somatic cells, and the telomere length is shorter in cancer cells than in normal cells (28). The telomere hypothesis postulates stabilization of telomere length and telomerase activation as key events in cellular immortalization and carcinogenesis (29). Accordingly, telomer- 
ase could be a novel and highly selective target for anticancer drug design, as confirmed by some factors that are believed to inhibit telomerase (30). The present study shows that the decrease in the telomerase activity of HL-60 cells was significantly increased by fraction FA-2-b- $\beta$ in a dose-dependent manner (Table 3). Hence, fraction FA-2-b- $\beta$, the bioactive RNA-protein complex from A. blazei Murill, could be a candidate for cancer therapy.

Elucidation of the molecular mechanism of apoptosis in cancer cells is very important in the field of anticancer research. Many reports have documented the pro-apoptosis qualities of A. blazei Murill extracts (26,3133). Only a few of these studies, however, have explored the molecular mechanisms, as was the case for caspase-9 (27).

Caspase is a member of the family of proteins containing a cysteine residue in their structure highly homologous to the ced-3 gene in nematodes. In recent years, at least 13 kinds of similar proteins were found in $C$. elegans (34). All factors inducing apoptosis will go through the caspase system (17). Caspase- 3 expression is the final key step for apoptosis in many cells (35). The present results indicate that, after treatment of HL60 cells with fraction FA-2-b- 3 for $96 \mathrm{~h}$, caspase-3 mRNA expression was greatly increased. Also, a ß-glucan in the extract of A. blazei can induce caspase- 9 activation by promoting p38 mitogen-activated protein kinase in HRA cells (27). Since caspase-9 is located closely upstream to caspase- 3 in the apoptosis cascade, when caspase- 9 is activated, it will stimulate caspase- 3 expression and lead to apoptosis. Our results are consistent with this conclusion. Furthermore, our study showed that the effect of fraction FA-2-b- 3 in inducing HL-60 cell apoptosis is positively correlated with caspase- 3 mRNA expression, and is negatively correlated with the decreased activity of telomerase. The results also strongly support the view that telomerase not only maintains tumor cell proliferation but also suppresses tumor cell apoptosis and differentiation through the depression of caspase (36).

In the apoptosis cascade there are many factors and signaling pathways that regulate the apoptosis process. Telomerase and caspase- 3 are important factors, but are only a small part of those acting in the cascade. Although telomerase and caspase- 3 could explain the mechanism of apoptosis, they do not explain all the details. In a recent review, Brajuskovic (37) reported that two major apoptosis pathways have been identified. One major apoptotic pathway involves cell surface death receptors that transmit an apoptotic signal on binding to a specific death ligand, such as tumor necrosis factor receptors. The second major apoptotic pathway involves mitochondria. Also, a large number of mitochondrial proteins participate in the regulation of apoptosis, especially cytochrome $\mathrm{C}$. Thus, many factors still need to be further studied for more in-depth understanding of the mechanism of apoptosis induction by fraction FA-2-b- 3 .

The present research indicated that fraction FA-2-b- $B$ can induce HL-60 cell apoptosis in vitro in both a time- and dose-dependent manner. We first determined that the primary mechanism of induction of HL60 cell apoptosis in vitro by fraction FA-2-b$B$ might be associated with the decrease of telomerase activity as well as the activation of caspase-3 mRNA expression in HL-60 cells. These results provide evidence for the use of fraction FA-2-b- $\beta$ in the clinical treatment of acute leukemia.

\section{Acknowledgments}

The authors wish to thank Prof. Junzhi Wang, National Institute for the Control of Pharmaceutical and Biological Products, China, for valuable discussions. The authors also thank the School of Medicine, Mie University, Japan, for providing the products of A. blazei Murill. 


\section{References}

1. Ohno N, Furukawa M, Miura NN, Adachi Y, Motoi M, Yadomae T. Antitumor beta glucan from the cultured fruit body of Agaricus blazei. Biol Pharm Bull 2001; 24: 820-828.

2. Takaku T, Kimura $\mathrm{Y}$, Okuda $\mathrm{H}$. Isolation of an antitumor compound from Agaricus blazei Murill and its mechanism of action. J Nutr 2001; 131: 1409-1413.

3. Mizuno M, Minato $\mathrm{K}$, Ito $\mathrm{H}$, Kawade M, Terai $\mathrm{H}$, Tsuchida H. Antitumor polysaccharide from the mycelium of liquid-cultured Agaricus blazei mill. Biochem Mol Biol Int 1999; 47: 707-714.

4. Sorimachi K, Akimoto K, Ikehara Y, Inafuku K, Okubo A, Yamazaki S. Secretion of TNF-alpha, IL-8 and nitric oxide by macrophages activated with Agaricus blazei Murill fractions in vitro. Cell Struct Funct 2001; 26: 103-108.

5. Delmanto RD, de Lima PL, Sugui MM, da Eira AF, Salvadori DM, Speit G, et al. Antimutagenic effect of Agaricus blazei Murill mushroom on the genotoxicity induced by cyclophosphamide. Mutat Res 2001; 496: 15-21.

6. Osaki Y, Kato T, Yamamoto K, Okubo J, Miyazaki T. Antimutagenic and bactericidal substances in the fruit body of a basidiomycete Agaricus blazei. Yakugaku Zasshi 1994; 114: 342-350.

7. Kimura Y, Kido T, Takaku T, Sumiyoshi M, Baba K. Isolation of an anti-angiogenic substance from Agaricus blazei Murill: its antitumor and antimetastatic actions. Cancer Sci 2004; 95: 758-764.

8. Mizuno T, Saito H, Nishitoba T, Nishitoba T, Kawagishi H. Antitumor active substances from mushrooms. Food Rev Intern 1995; 11: 2361.

9. Tokunaka K, Ohno N, Adachi Y, Tanaka S, Tamura H, Yadomae T. Immunopharmacological and immunotoxicological activities of a water-soluble $(1 \rightarrow 3)$-beta-D-glucan, CSBG from Candida spp. Int $J$ Immunopharmacol 2000; 22: 383-394.

10. Grynberg NF, Carvalho MG, Velandia JR, Oliveira MC, Moreira IC, Braz-Filho R, et al. DNA topoisomerase inhibitors: biflavonoids from Ouratea species. Braz J Med Biol Res 2002; 35: 819-822.

11. Song G, Mao YB, Cai QF, Yao LM, Ouyang GL, Bao SD. Curcumin induces human HT-29 colon adenocarcinoma cell apoptosis by activating p53 and regulating apoptosis-related protein expression. Braz J Med Biol Res 2005; 38: 1791-1798.

12. Mizuno T, Hagiwara $T$, Nakamura $T$, Ito $H$, Shimura $K$, Sumiya $T$, et al. Antitumor activity and some properties of water-soluble polysaccharides from 'Himematsutake', the fruiting body of Agaricus blazei Murill. Agric Biol Chem 1990; 54: 2889-2896.

13. Tian $X$, Lun Z, Wang J, Ito $H$, Shimura K. Clinical observation on treatment of acute nonlymphocytic leukemia with Agaricus blazei. $J$ Lanzhou Med College 1994; 20: 169-171.

14. Hussain RF, Nouri AM, Oliver RT. A new approach for measurement of cytotoxicity using colorimetric assay. J Immunol Methods 1993; 160: 89-96.

15. Yoshida A, Shao RG, Pommier Y. Assesment DNA damage during apoptosis. In: Studzinski GP (Editor), Apoptosis. London: Oxford University Press; 1999. p 41-55.

16. Kim NW, Piatyszek MA, Prowse KR, Harley CB, West MD, Ho PL, et al. Specific association of human telomerase activity with immortal cells and cancer. Science 1994; 266: 2011-2015.

17. Yakovlev AG, Knoblach SM, Fan L, Fox GB, Goodnight R, Faden AI. Activation of CPP32-like caspases contributes to neuronal apoptosis and neurological dysfunction after traumatic brain injury. $J$ Neurosci 1997; 17: 7415-7424.

18. Kolenko VM, Uzzo RG, Bukowski R, Finke JH. Caspase-dependent and -independent death pathways in cancer therapy. Apoptosis 2000; 5: 17-20.

19. Ahn WS, Kim DJ, Chae GT, Lee JM, Bae SM, Sin Jl, et al. Natural killer cell activity and quality of life were improved by consumption of a mushroom extract, Agaricus blazei Murill Kyowa, in gynecological cancer patients undergoing chemotherapy. Int $J$ Gynecol Cancer 2004; 14: 589-594

20. Mizuno M, Morimoto M, Minato K, Tsuchida H. Polysaccharides from Agaricus blazei stimulate lymphocyte T-cell subsets in mice. Biosci Biotechnol Biochem 1998; 62: 434-437.

21. Takimoto H, Wakita D, Kawaguchi K, Kumazawa Y. Potentiation of cytotoxic activity in naive and tumor-bearing mice by oral administration of hot-water extracts from Agaricus blazei fruiting bodies. Biol Pharm Bull 2004; 27: 404-406.

22. Kuroiwa Y, Nishikawa A, Imazawa T, Kanki K, Kitamura Y, Umemura $\mathrm{T}$, et al. Lack of subchronic toxicity of an aqueous extract of Agaricus blazei Murrill in F344 rats. Food Chem Toxicol 2005; 43: $1047-$ 1053.

23. Zhang X, Wang J, Mao X, Ito H, Shimura K. Effects of Agaricus blazei on bone marrow pluripotent haematopoietic stem cells and haematopoietic progenitors of normal mice. J Lanzhou Med College 1993; 19: 143-145.

24. Zhang X, Wang J, Wang J. An experimental study on effect of Agaricus blazei on hematopoietic cells in bone marrow and hemopoietic stimulatory factor of radiation injury mice. Chinese $J$ Radiat Mediation Protect 1993; 6: 459.

25. Wang J, Mao X, Chen R, Wang J, Ito H, Shimura K. Clinical observation on the effects of Agaricus blazei to gastrointestinal malignancies. Gansu Med 1994; 13: 5-6.

26. Koyama Y, Katsuno Y, Miyoshi N, Hayakawa S, Mita T, Muto H, et al. Apoptosis induction by lectin isolated from the mushroom Boletopsis leucomelas in U937 cells. Biosci Biotechnol Biochem 2002; 66: 784-789.

27. Kobayashi H, Yoshida R, Kanada Y, Fukuda Y, Yagyu T, Inagaki K, et al. Suppressing effects of daily oral supplementation of betaglucan extracted from Agaricus blazei Murill on spontaneous and peritoneal disseminated metastasis in mouse model. J Cancer Res Clin Oncol 2005; 131: 527-538.

28. Boklan J, Nanjangud G, MacKenzie KL, May C, Sadelain M, Moore MA. Limited proliferation and telomere dysfunction following telomerase inhibition in immortal murine fibroblasts. Cancer Res 2002; 62: 2104-2114.

29. Greider CW. Telomerase activity, cell proliferation, and cancer. Proc Natl Acad Sci USA 1998; 95: 90-92.

30. Hayakawa N, Nozawa K, Ogawa A, Kato N, Yoshida K, Akamatsu K, et al. Isothiazolone derivatives selectively inhibit telomerase from human and rat cancer cells in vitro. Biochemistry 1999; 38: 11501 11507.

31. Fujimiya Y, Suzuki Y, Oshiman K, Kobori H, Moriguchi K, Nakashima $\mathrm{H}$, et al. Selective tumoricidal effect of soluble proteoglycan extracted from the basidiomycete, Agaricus blazei Murill, mediated via natural killer cell activation and apoptosis. Cancer Immuno Immunother 1998; 46: 147-159.

32. Fujimiya Y, Suzuki Y, Katakura R, Ebina T. Tumor-specific cytocidal and immunopotentiating effects of relatively low molecular weight products derived from the basidiomycete, Agaricus blazei Murill. Anticancer Res 1999; 19: 113-118.

33. Barbisan LF, Miyamoto M, Scolastici C, Salvadori DM, Ribeiro LR, 
Eira AF, et al. Influence of aqueous extract of Agaricus blazei on rat liver toxicity induced by different doses of diethylnitrosamine. $J$ Ethnopharmacol 2002; 83: 25-32.

34. Lettre G, Hengartner MO. Developmental apoptosis in $C$. elegans: a complex CEDnario. Nat Rev Mol Cell Biol 2006; 7: 97-108.

35. Salvesen GS, Dixit VM. Caspase activation: the induced-proximity model. Proc Natl Acad Sci USA 1999; 96: 10964-10967.

36. Kondo S, Tanaka Y, Kondo Y, Hitomi M, Barnett GH, Ishizaka Y, et al. Antisense telomerase treatment: induction of two distinct pathways, apoptosis and differentiation. FASEB J 1998; 12: 801-811.

37. Brajuskovic GR. Apoptosis in malignant diseases. Arch Oncol 2005; 13: $19-22$ 